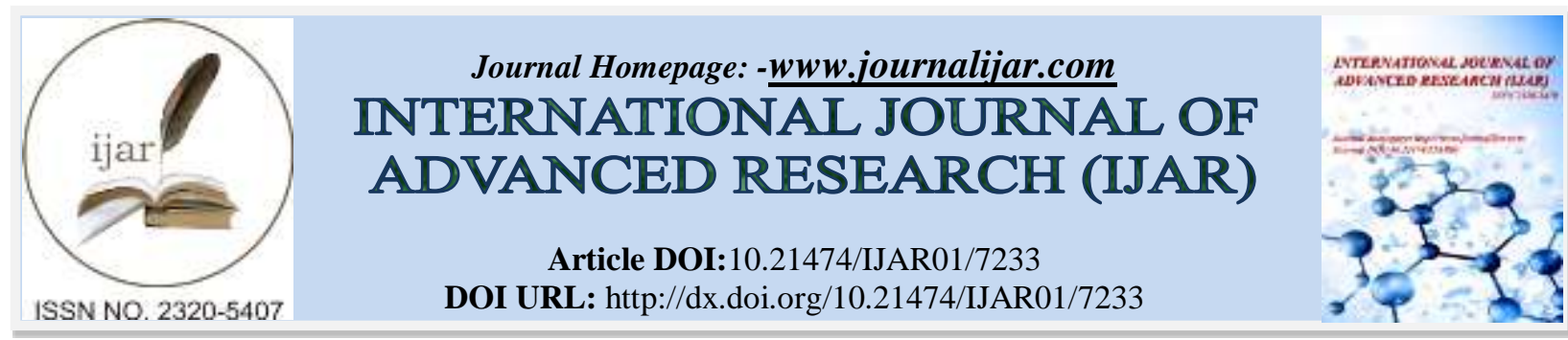

RESEARCH ARTICLE

\title{
EVALUATING STUDENTS' LEARNING STYLES TO IMPROVE EDUCATIONAL PRACTICES FOR A WEB DEVELOPMENT COURSE.
}

\author{
Samuel-Soma M. Ajibade ${ }^{1,2}$, Nor Bahiah Ahmad ${ }^{2}$ and Siti Mariyam Shamsuddin ${ }^{1,2}$. \\ 1. UTM Big Data Centre, UTM, Malaysia. \\ 2. Faculty of Computing, Universiti Teknologi Malaysia, Skudai, Johor, Malaysia.
}

\section{Manuscript Info}

Manuscript History

Received: 08 April 2018

Final Accepted: 10 May 2018

Published: June 2018

Keywords:-

Learning Style, Students' Learning

Style, Students' performances

\begin{abstract}
The process of learning is a very imperative features of human life and the learning styles of learners has been one of the essential acquired issues. In the aspect of learning, each learner has their learning styles which influences their way of acquiring, developing, comprehending and perceiving information. Analyzing the individual learning styles of learners brings improvement to the performance of their learning process and upsurge the learning progress of the learners. The aim of this research is to determine the learning styles of learners in a Nigerian higher Institution so as to advance instructional strategies for Entrepreneurship Education Courses (EED) to be carried out in years to come. This study was carried out in the 2017/2018 academic session. A total of 31 students in a web development course which is part of the entrepreneurship courses offered in the Entrepreneurship Centre of the institution took part in the study. According to the acquired statistics from this research, it was established that the learning style profiles of learner's differs across the various skilled courses of the centre of the institution.
\end{abstract}

Copy Right, IJAR, 2018,. All rights reserved.

\section{Introduction:-}

In recent times, there has been much more concentration on numerous aspects of learning styles by academic researchers and how they can be considered in educational technology. Studies on learning styles in technologyenhanced learning were carried out and the establishment of many adaptive systems whose purpose is to integrate learning styles and make provision for courses that are suitable for the distinct styles of student learning (Hwang, Chiu et al. 2015, Wongwatkit, Srisawasdi et al. 2017). The research area of learning styles is difficult and this is affected by so many factors, which thereby points to various views and concepts. Furthermore, there are lots of various and numerous models of learning styles that are embedded in various literature, such as the learning style model by Kolb (Honey and Mumford 1992, Kolb 2014), Honey and Mumford (Honey and Mumford 2000, Truong 2016), and Felder and Silverman (Felder and Silverman 1988, Amara, Bendella et al. 2015). Even though many issues are still opened with respect to styles of learning, all of the models of learning style are of the larger opinions that the learners have various ways in which they prefer to learn.

The process of learning involves perceptual and cognitive abilities of students in numerous means. Students perceive, process and represent materials that are separately used for learning; and they have various priorities for types, number and order of learning resources. Typically, a set of attitudes and behaviours that defines an 
individual's desired learning method is known as a learning style (Bowen 2018). While there is various learning style models, researchers concur that it is conceivable to analyse student's learning style and that students with a predominant preference for a particular learning style may experience issues in gaining information in condition where it's not well-suited with the instructing methodology (Dwyer 2015).

Learning style is the method for individual to obtain, sustain up and encourage the comprehension of acquired knowledge (Sekaran and Bougie 2016, Blachowicz and Ogle 2017). Every individual has different approaches to learn. Some get a kick out of the chance to learn by observing, hear, react, offer intelligent reason, recall and learn by utilizing graphical designs (Winebrenner and Kiss 2017). Learning styles is an approach to learn (Entwistle and Ramsden 2015) and every student has diverse learning styles. Likewise, learning styles can fluctuate incredibly based on individual encounters. Learning styles influence student's academic accomplishments (Ovando and Combs 2018).

\section{Literature Review:-}

There is a more prominent acknowledgment of our need to acquire a more profound comprehension of our learners, their learning contrasts, learning styles, learning troubles and their inclination to specific sorts of responsibilities to accomplish their objectives effectively (Olson 2015). In addition, there is a lot of confirmation that a disparity between student's learning styles and educator's instructional style may negatively affect classroom learning (Best and Kahn 2016, Ashman and Conway 2017). Nigerian students are no special case to this rule; they are maybe confronting much more troubles because of the disparity which exists amongst instructing and learning styles. Numerous Nigerian tutors who are the result of an educational system which is more traditional, don't appear to know about the styles of their students and simply attempt to draw upon a predetermined number of teaching styles inside their usual range of familiarity. It ought to be noticed that few researches have tended to the connection that exist between perceptual learning and the styles of teaching in Nigeria (Brown 2000, Coleman 2015, Scott 2017)

\section{Concept and Definition of learning styles:-}

The definition of learning styles depends on the theory of learning. (Riechmann and Grasha 1974) characterized learning styles as individual characteristics that impact a student's capacity to gain knowledge, to collaborate with peers and the instructor, and to take an interest in learning encounters. (Kolb 1984), in his Experiential Learning Theory, characterized the learning style as an impression of how thought is handled. As indicated by (Felder and Silverman 1988) the learning style is characterized as the way data is being obtained and processed. Besides, (James and Gardner 1995) recommended that the way by which each students respond to the general learning environment make up the person's learning style.

A review of the literature uncovers numerous researches exploring the connection between the learning styles of students and their performances academically. For instance, one of these reviews was led by (Chen, Wang et al. 2015). They researched the impacts of developmental appraisal and learning style on student's performances in a Web-based learning condition and they revealed that the learning style is a huge factor influencing the accomplishment of students.

\section{Dimension of Felder-Silverman Learning style:-}

There are a few distinctive models of learning style including (Kolb 1984), (Honey and Mumford 2000), and (Felder and Silverman 1988) and each models proposes diverse depictions and characterizations of learning styles. In our study, we are concentrating on the Felder-Silverman learning style model (FSLSM). Most other learning style models arrange students into various groups, though Felder and Silverman defines the learning style of a student in more detail, recognizing inclinations on four dimensions. An additional core variance is that FSLSM depends on propensities, demonstrating that students with a high priority for some particular conduct can likewise act in some cases in an unexpected way. FSLSM is utilized all the time in research related with learning styles in advanced learning innovations. As indicated by (Carver and Scheier 1999, Feldman, Monteserin et al. 2015) the Felder Model is most fitting for hypermedia courseware. (Christian 2015) affirmed this by leading a correlation of learning style models as for the application in e-learning and Web-based learning frameworks. Accordingly, they likewise propose FSLSM as the most suitable model.

The Felder-Silverman learning style display is verified utilizing the Felder and Soloman's ILS. ILS instrument was shared into four dimensions and the four sub-scales of Procession (Active/Reflective learners), Perception (Sensing/Intuitive learners), Input (Visual/Verbal learners) and Comprehension (Sequential/Global learners). Each 
dimension of learning styles are linked with eleven (11) choice items, with each option ('a' or 'b') equivalent to each dimension individually. The respondents are asked to select one of the answers provided.

The characteristics of each learning style with respect to FSLSM are described and the relevant patterns for identifying learning styles for each dimension are presented in Table 1.1 below:

\begin{tabular}{|c|c|c|}
\hline Dimensions of learning & Sub-scales & Description \\
\hline $\begin{array}{l}\text { Active/Reflection } \\
\text { Learners }\end{array}$ & Procession & $\begin{array}{l}\text { ACTIVE LEARNERS: Active learners love to try something out by } \\
\text { experiments and do not like to learn through lectures. More so, they } \\
\text { also like to learn and work in groups than to work alone. They } \\
\text { easily remember information. They share, discuss and explain } \\
\text { knowledge acquired with friends. } \\
\text { REFLECTIVE LEARNERS: Reflective learners loves to learn } \\
\text { through thinking. They independently learn and work. After } \\
\text { acquiring information they think before explaining to friends. They } \\
\text { as well prefer lecture learning that allows them to think about the } \\
\text { acquired information. They rather learn in theory. }\end{array}$ \\
\hline Sensing/Intuitive Learners & Perception & $\begin{array}{l}\text { SENSING LEARNERS: The sensing learners mostly involve } \\
\text { learning facts only. They practice learning styles with information, } \\
\text { has the advantage of considering the facts and doing hands-on } \\
\text { activities. They also try to solve problems regularly with relevant } \\
\text { examples, more thorough in carrying out practical work. } \\
\text { INTUITIVE LEARNERS: This refers to students being abstract, } \\
\text { inventive and orientated towards theory and purpose. These students } \\
\text { tend to look for reasons, possibilities and relevance. They better get } \\
\text { to understand fresh ideas and always comfortable with abstract } \\
\text { ideas and mathematical formulas. }\end{array}$ \\
\hline Visual/Verbal Learners & Input & $\begin{array}{l}\text { VISUAL LEARNERS: Visual students easily remember what they } \\
\text { see in photographs, drawings, diagrams, series, films, and } \\
\text { demonstrations. They prefer teaching aids and the use of graphic } \\
\text { presentation in the teaching process. They easily remember things } \\
\text { by sight. } \\
\text { VERBAL LEARNERS: Verbal learners prefer to learn via words and } \\
\text { 'explanation argument'. Explanations are preferred via writing, } \\
\text { orally or discussions conducted in class and like to read out loud } \\
\text { and repeat it several times. }\end{array}$ \\
\hline $\begin{array}{l}\text { Sequential/Global } \\
\text { Learners }\end{array}$ & Comprehension & $\begin{array}{l}\text { SEQUENTIAL LEARNERS: Sequential learners are likely to } \\
\text { understand things easily systematically and sequentially. This } \\
\text { learners find it easy to remember and understand when teaching is } \\
\text { sequentially delivered, from easy to difficult, and by logical steps. } \\
\text { They like to learn in a structured manner that shows a strong } \\
\text { connection with what has been previously taught. } \\
\text { GLOBAL LEARNERS: Global learners are intense in gathering } \\
\text { information needed at random, and they get to understand } \\
\text { information spontaneously based on acquired information. They can } \\
\text { obtain any kind of information, either organized or not, they } \\
\text { promptly solve complex problems and they relate one thing to } \\
\text { another. }\end{array}$ \\
\hline
\end{tabular}

\section{Methodology:-}

Aspects discussed are population and sample, research instruments and data collection procedures

\section{Population and Sample:-}

The pilot study was conducted during the second semester of 2016/2017 academic year. A total number of 31 students belonging to different departments of the institution but all offering a compulsory entrepreneurship institution wide course which in this case is a web development course at The Federal Polytechnic, Ado, Nigeria 
participated in the study. The entrepreneurship skilled course is a compulsory general course for all students of the institution from year 1 to the $4^{\text {th }}$ year which is taken at the Entrepreneurship Centre of the institution. The web development course is one of the various courses offered in the centre. The participants are all $3^{\text {rd }}$ year students of the institution.

\section{Research Instrument:-}

In order to determine the learning styles of the students, Index of Learning Styles (ILS) developed by Felder and Solomon (1991) was used as an instrument. ILS is an instrument chosen by the researchers because questionnaire is also able to help and facilitate the samples on answering the items. The ILS consists of 44 questions in order to analyse learning preferences of students on the four dimensions of (Felder and Silverman 1988) learning style model. The researchers elected to use the Felder Silverman ILS (Felder and Silverman 1988), because students are able to self-administer this questionnaire at no cost. In addition, the four learning styles dimensions are numerically coded and could be easily quantified for analysis. The ILS has been validated (Dascalu, Bodea et al. 2015, Buckley and Doyle 2017).

According to the model on which the ILS is based, there are four dimensions of learning style, with each dimension having two opposite categories (such as active and reflective). The reported score for a dimension indicates your preference for one category or the other.

If your score for a dimension is 1 or 3 , you are fairly well balanced on the two categories of that dimension and it is represented on the vertical axis of the chart by 3 , with only a mild preference for one or the other.

If your score for a dimension is 5 or 7 , you have a moderate preference for one category of that dimension and it is represented on the vertical axis of the chart by 2. You may learn less easily in an environment that fails to address that preference at least some of the time than you would in a more balanced environment.

If your score for a dimension is 9 or 11 , you have a strong preference for one category of that dimension and it is represented on the vertical axis of the chart by 1. You may have difficulty learning in an environment that fails to address that preference at least some of the time.

The results obtained from the respondents were used to identify the learning styles practiced in the entrepreneurship course.

\section{Results:-}

In order to analyse the learning styles of students, the score of the students' ILS sub dimension was observed.

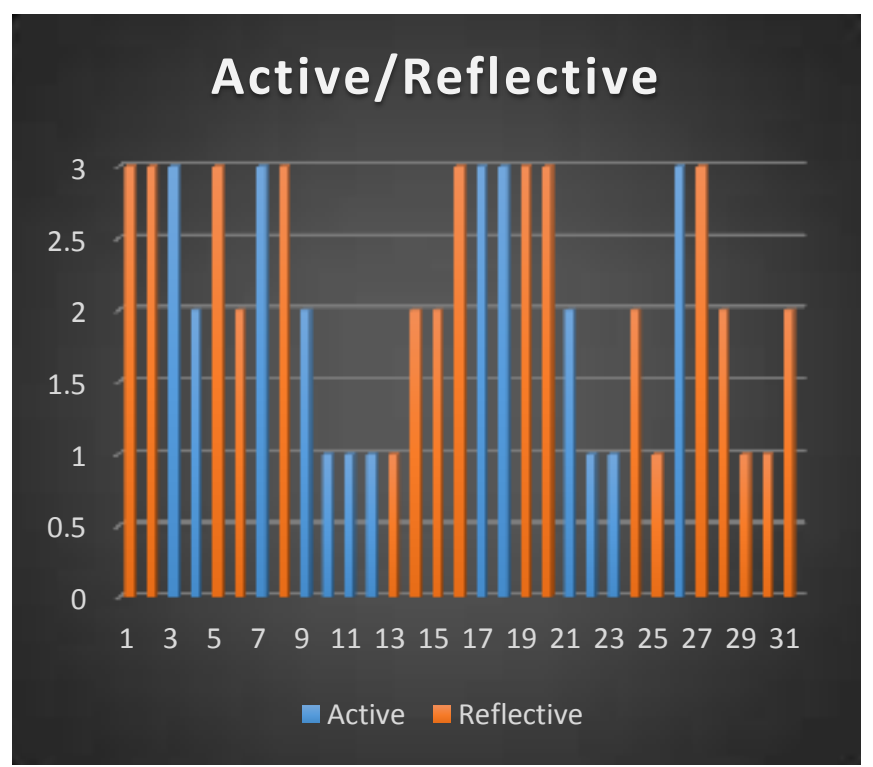

Figure 1:-Scores of students on active/reflective dimension of ILS 
As seen in Figure 1, most of the students are fairly well balanced on active/reflective dimension and they have mild preference for being reflective than being active.

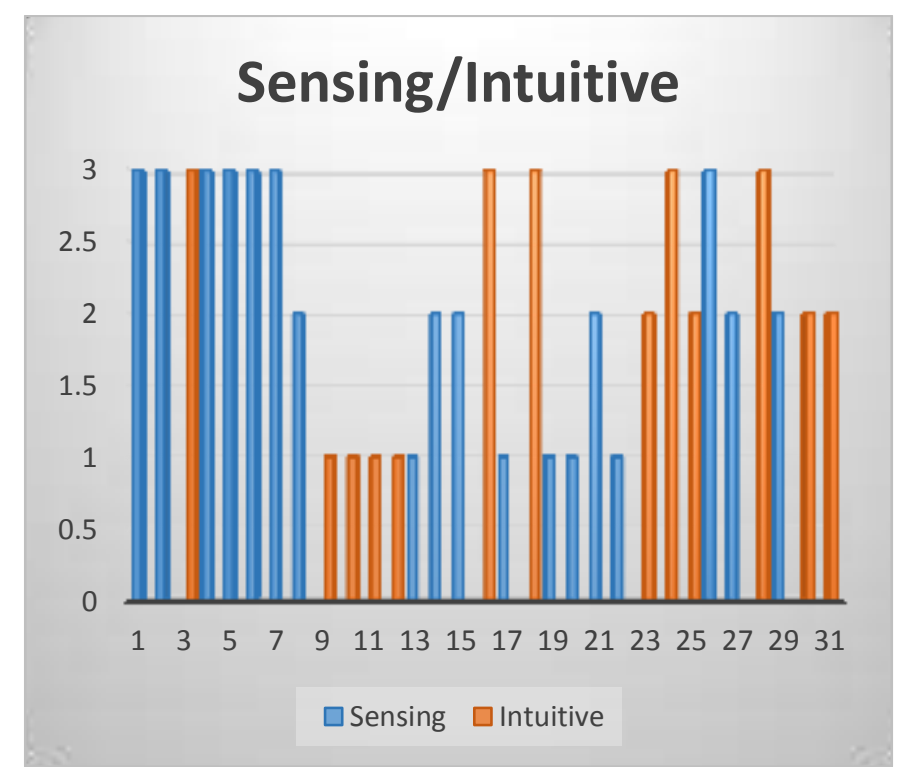

Figure 2:-Scores of students on sensing/intuitive dimension of ILS

The result in Figure 2 shows that most of the students are well balanced on sensing/intuitive dimension and they have mild preference for sensing than being intuitive.

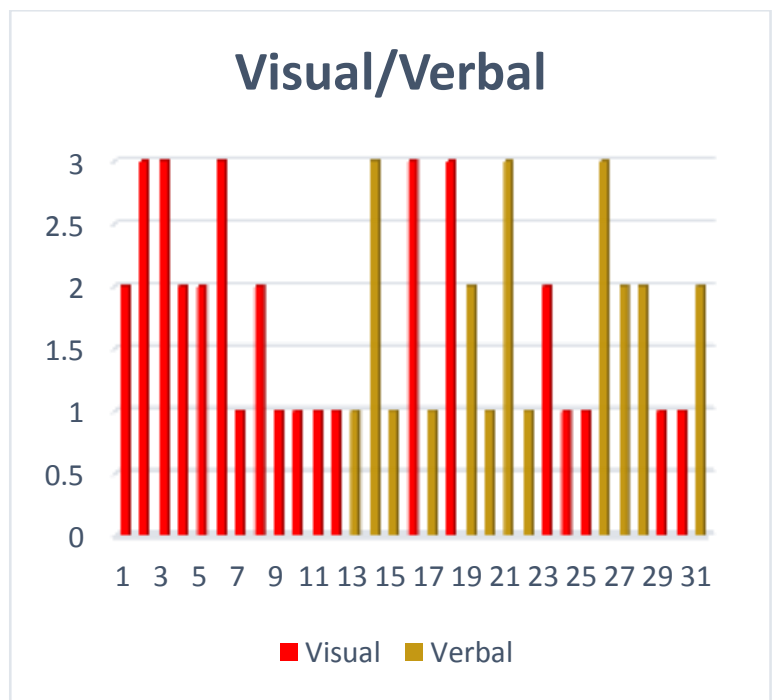

Figure 3:-Scores of students on visual/verbal dimension of ILS

According to Figure 3, the results indicates that a larger number of the students have strong preference for one category of the dimension which is visual. 


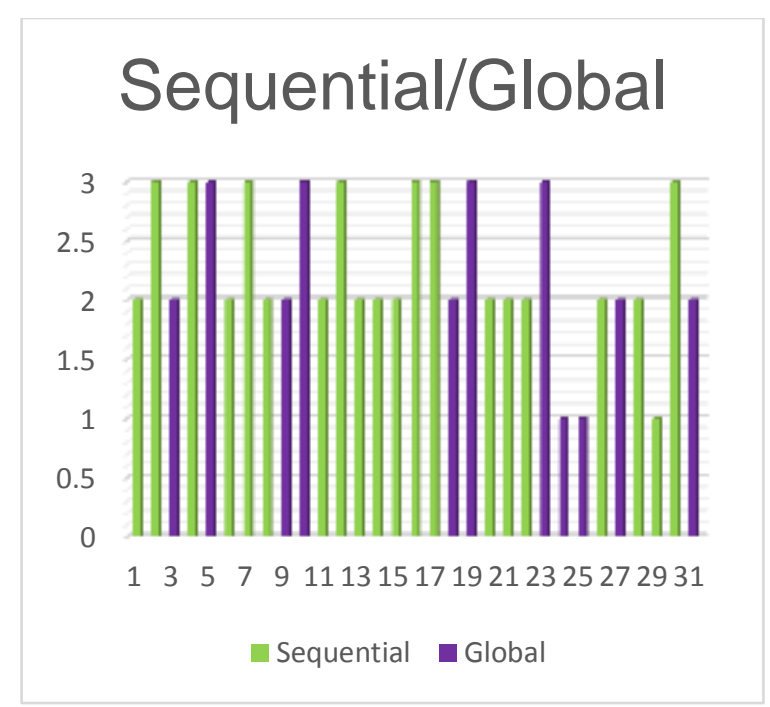

Figure 4:-Scores of students on sequential/global dimension of ILS

In Figure 4, the result represents that most of the students have a moderate preference for one category of the dimension which is sequential. The students are more sequential in their learning than being global.

\section{Discussions and Conclusion:-}

The purpose of this study was mainly to define the learning styles of students at the entrepreneurship centre of The Federal Polytechnic, Ado so as to improve the instructor's style of teaching for Entrepreneurship Education Courses. Therefore the following conclusions can be drawn according to the preferences of the students' learning as pertaining the dimensions of ILS. The students offered the same entrepreneurship course as a compulsory general course of the institution but are from various departments of the institution, however many students have similar learning style profile. Also the students were well balanced on active/reflective ILS dimension and balanced on sensing/intuitive dimension of ILS, while a larger number of the students have strong preference for one category of the dimension than the order which is visual. The students are also more sequential in their learning than global.

According to the results shown, the design for the teaching strategy of the instructor should be well tailored towards a path that will improve the learning styles and academic performances of students and this can be done by probably channeling the course materials to suit the most preferred learning styles of students which will at the long run give them better academic performances. Finally, it is recommended that other courses of the institution both departmental courses and the general wide courses should be studied as pertaining their learning style and this will in turn improve the performances of students as this is the first research so far that has studied the learning styles of students in the institution. Also, the researchers plan to adopt other learning styles to analyze many other courses offered in the institution. 


\section{References:-}

1. Amara, S., et al. (2015). "Using students' learning style to create effective learning groups in MCSCL environments."

2. Ashman, A. F. and R. N. Conway (2017). Using cognitive methods in the classroom, Routledge.

3. Best, J. W. and J. V. Kahn (2016). Research in education, Pearson Education India.

4. Blachowicz, C. and D. Ogle (2017). Reading comprehension: Strategies for independent learners, Guilford Publications.

5. Bowen, H. (2018). Investment in learning: The individual and social value of American higher education, Routledge.

6. Brown, H. D. (2000). "Principles of language learning and teaching."

7. Buckley, P. and E. Doyle (2017). "Individualising gamification: An investigation of the impact of learning styles and personality traits on the efficacy of gamification using a prediction market." Computers \& Education 106: $43-55$.

8. Carver, C. S. and M. F. Scheier (1999). "Themes and issues in the self-regulation of behavior." Advances in social cognition 12(1): 1.

9. Chen, C.-H., et al. (2015). "The comparison of solitary and collaborative modes of game-based learning on students' science learning and motivation." Journal of Educational Technology \& Society 18(2): 237.

10. Christian, S. (2015). IT as a social and learning tool for international students: a case study in ICT education: a thesis presented in a partial fulfilment of the requirements for Masters of Information Science (IT) at Massey University, Auckland, New Zealand, in 2015, Massey University.

11. Coleman, J. S. (2015). Education and Political Development.(SPD-4), Princeton University Press.

12. Dascalu, M.-I., et al. (2015). "A recommender agent based on learning styles for better virtual collaborative learning experiences." Computers in Human Behavior 45: 243-253.

13. Dwyer, L. A. (2015). Mapping impact: an analysis of the Dudley Street Neighborhood Initiative Land Trust, Massachusetts Institute of Technology.

14. Entwistle, N. and P. Ramsden (2015). Understanding student learning (Routledge revivals), Routledge.

15. Felder, R. M. and L. K. Silverman (1988). "Learning and teaching styles in engineering education." Engineering education 78(7): 674-681.

16. Feldman, J., et al. (2015). "Automatic detection of learning styles: state of the art." Artificial Intelligence Review 44(2): 157-186.

17. Honey, P. and A. Mumford (1992). "The manual of learning styles."

18. Honey, P. and A. Mumford (2000). The learning styles helper's guide, Peter Honey Publications Maidenhead.

19. Hwang, G.-J., et al. (2015). "A contextual game-based learning approach to improving students' inquiry-based learning performance in social studies courses." Computers \& Education 81: 13-25.

20. James, W. B. and D. L. Gardner (1995). "Learning styles: Implications for distance learning." New directions for adult and continuing education 1995(67): 19-31.

21. Kolb, D. A. (1984). "Experiental learning." Englewood cliffs.

22. Kolb, D. A. (2014). Experiential learning: Experience as the source of learning and development, FT press.

23. Olson, M. H. (2015). An introduction to theories of learning, Psychology Press.

24. Ovando, C. J. and M. C. Combs (2018). Bilingual and ESL classrooms: Teaching in multicultural contexts, Rowman \& Littlefield.

25. Riechmann, S. W. and A. F. Grasha (1974). "A rational approach to developing and assessing the construct validity of a student learning style scales instrument." The Journal of Psychology 87(2): 213-223.

26. Scott, J. (2017). Social network analysis, Sage.

27. Sekaran, U. and R. Bougie (2016). Research methods for business: A skill building approach, John Wiley \& Sons.

28. Truong, H. M. (2016). "Integrating learning styles and adaptive e-learning system: Current developments, problems and opportunities." Computers in human behavior 55: 1185-1193.

29. Winebrenner, S. and L. M. Kiss (2017). Teaching kids with learning difficulties in today's classroom: How every teacher can help struggling students succeed, Free Spirit Publishing.

30. Wongwatkit, C., et al. (2017). "Influence of an integrated learning diagnosis and formative assessment-based personalized web learning approach on students learning performances and perceptions." Interactive Learning Environments 25(7): 889-903. 